\title{
Wills of 'Wajibah' and Renewal Thoughts of Islamic Inheritance Law in Indonesia
}

\author{
Ismail \\ IAIN Bukit Tinggi \\ Email: ismailnovel68@gmail.com
}

\begin{abstract}
The Will of 'Wajibah' has been implemented in several Muslim countries, it is still debated. According to the majority of fiqh scholars, the obligation of will for a Muslim who is close to his death has been abolished by inheritance law. In addition, they argue that a will is 'ikhtiyâriyah' or an act of 'ikhtiyâriyah', the act depends on a person's will, and it is not enforced by force (ijbariyah). This study tries to answer the controversy with the sub-problems of the actual concept of the mandatory will, the legal basis used by Islamic juries in determining the law, and how its reforms. This research is qualitative with a literature study and the sources used to include some 'fiqh' books and law books. To analyze the data, the author used content analysis methods, through inductive, deductive, and comparative thinking methods. The results of this study indicate that the mandatory will is new 'ijtihad' in the treasury of 'ijtihad'. This concept was born from the reinterpretation of the will and inheritance verses by relating them to the context of today's social life with considerations of benefit or 'mashlahah mursalah'.
\end{abstract}

Keywords: renewal, 'ijtihad', Islamic law, wills of 'Wajibah'

\begin{abstract}
Abstrak: Wasiat wajibah meskipun telah berlaku di beberapa negara Muslim, masih mengundang perdebatan, antara lain disebabkan karena menurut pendapat mayoritas atau jumhur ulama fiqh kewajiban berwasiat bagi seorang Muslim yang telah mendekati masa kematiannya itu telah dihapuskan oleh hukum waris. Di samping itu, mereka juga berpendapat bahwa wasiat adalah perbuatan yang bersifat ikhtiyâriyah, yakni ada tidaknya wasiat tersebut tergantung kepada kehendak seseorang, tidak berlaku secara paksa (ijbâriyah). Penelitian ini, mencoba menjawab kontroversi sebagaimana dikemukakan di atas dengan sub masalah bagaimana sebenarnya konsep wasiat wajibah tersebut, apa landasan hukum yang digunakan oleh para juris Islam dalam menetapkan hukumnya dan bagaimana pembaruan yang terjadi di dalamnya. Jenis penelitian ini adalah kualitatif dengan studi kepustakaan yang menjadikan sejumlah kitab fiqh dan kitab undang-undang sebagai sumbernya. Analisis dilakukan dengan metode konten analisis, melalui metode berpikir induktif, deduktif dan komparatif. Hasil dari penelitian ini menunjukkan bahwa wasiat wajibah sejatinya merupakan ijtihad baru dalam khasanah ijtihad. Konsep ini lahir dari penafsiran ulang terhadap ayat-ayat wasiat dan ayat-ayat waris dengan mengaitkannya dengan konteks kehidupan sosial masyarakat sekarang dengan pertimbangan kemashlahatan atau mashlahah mursalah.
\end{abstract}

Kata-kata kunci: pembaruan, ijtihad, hukum islam, wasiat wajibah 


\section{Introduction}

The mandatory "wills of 'wajibah" originally appeared with the issues of preventing some heirs to obtain such inheritance, while they were worthy to obtain their inheritance. By carrying out the inheritance law, some relatives are very deserving of the inheritance. Other relatives who are closer than him or his, the prevention of obtaining the inheritance occurs as a consequence. Take a look at orphaned grandchildren and their uncles and aunts who become heirs or heiresses. According to Islamic inheritance law, they are prevented or ('terhijab') by their uncles or aunts. The orphaned grandchildren are in need more than their uncles or aunts.

The concept of 'wills of wajibah' was adopted by several Islamic countries into their legislation. The first Islamic country to incorporate 'wills of wajibah' into its legislation was Egypt, which made it an important part of the Egyptian Will Law no.71/1946. Then followed by Syria through the Syrian Individual Law No. 59/1953, which was later amended by Law no. 34/1975; Tunisia through the Tunisian Personal Status Law of 1956, which was later amended by Law no. 70/1958, Law no. 41/1962, No. 1/1964, 49/1966, and No. 7/1981; then followed by Morocco with the Moroccan Individual Status Act 1957-1968; Iraq through the 1959 Iraqi Law; Kuwait through the Mandatory Will Law no. 5/1971; Jordan with Jordanian Personal Status Law No. 61/1976 which was later amended by Law no. 25/1977; and Algeria with the Algerian Family Law Law No. 11/1984 ${ }^{1}$ Then in 1991, there was also a legal regulation regarding the wills of 'Wajibah' in Indonesia through the Compilation of Islamic Law in Indonesia.

The establishment of wills of 'wajibah' raises various problems, both Egypt and other Islamic countries as well as Indonesia. According to the majority of 'fiqh' scholars, the obligation of will for a Muslim (who is nearing his death period) has been abolished by inheritance law. In addition, they also argue that 'wills' is an act of 'ikhtiyâriyah', i.e. whether there are wills or not depends on the wills of a person', not being enforced by force (ijbariyah).

This article attempts to objectively examine the concept of wills of 'Wajibah', the legal basis or basis law used by scholars in establishing the wills of 'Wajibah' as a law, and the reforms that occurred regarding this wills of 'wajibah'. This research is library research with some references such as 'Fiqh' books and law. The analysis is carried out using content analysis (content analysis) with inductive, deductive, and comparative ways of thinking techniques.

\section{Genealogy and Legal Basis of Wills of 'Wajibah'}

The term 'Wajibah' is not very known in the 'fiqh' classic, it just appeared in the Egyptian will law ${ }^{3}$. However, the law, both in the articles of the law and its explanations, does not contain a clear understanding or a definitive understanding of the intended wills of 'wajibah'. However, this does not mean that the law is empty of a meaning of 'wajibah'. Abu Zahrah, in his explanation, stated clearly that the wills

1Mustafa al-Siba'i, al-Ahkâm al-Ahliyahal-Washiyah, Dimasyq: Matabi' Jami'ah Dimasyq), Tahir Mahmood, Family Reform in The Muslim World, (Bombai: NM. Tripathi PVT LTD, 1972), and Tahir Mahmood, Personal Law in Islamic Countries, (New Delhi: Academic in law and Regional).

${ }^{2}$ Hasbi Ash-Shiddieqy, Fiqh al-Mawaris, Hukum-Hukum Warisan dalam Syari'at Islam, (Jakarta: Bulan Bintang, 1973), pp. 292-293.

${ }^{3}$ Rizkal, Pemberian Hak Waris Dalam Hukum Islam kepada Non-Muslim Berdasarkan Wasiat Wajibah, Jurnal Yudisial Vol. 9 No. 2 , 2016, 180. 
of 'wajibah' in the Egyptian Will Law was taken from one of the religious laws that are takliffi $i^{4}$ or calls as mandatory. Then a form of will is formulated and charged to heirs or heiress to carry it out. If they do not carry out the will, the will is carried out according to the law ${ }^{5}$. This kind of will by law is reserved for orphaned grandchildren, whose parents died when their grandparents were still alive, then when their grandparents died, neither gave them a will. Such provisions are contained in Article 76 of the Egyptian Will Law No. 71/1946, which reads as follows:

Translation: If someone who dies, does not make a will for the descendants of his child who died before or at the same time as him, in the number of shares that should have been received by his child from the inheritance, the descendants of his child will receive a share of the share that should have been received by their parents by inheritance. if he was still alive at that time through a will, with a maximum limit of one-third of the inheritance 6 .

From the information above, the will of 'Wajibah' according to the Egyptian will law no. 71/1946 can be defined by a mandatory will which is stipulated by law to a person who died for the descendants of his child who had died before or at the same time as him, in the amount of the share that should be received by his child by inheritance (if the child is still alive).

The legal basis used as a reference for the above law is the view of the majority of Muslim scholars, such as Shu'bi, al-Nahk'i, Tsauri, Malik, Shafi'i, and the ra'yi expert group, the legal will is not mandatory. Ibn Abd al-Barr said that those mentioned above have agreed that the will is not obligatory, except for those who have obligations that have not been fulfilled, such as debts that do not have evidence or deposits that do not have witnesses ${ }^{7}$.

There are several reasons put forward by the majority of scholars in expressing their opinion, namely: First, there is no history that tells about the prohibition and obligation of wills. If the will is mandatory or prohibited, of course, there will be a clear history that comes from the history of 'Sahabat' (friends of the Prophet); Second, the will is a form of gift during life and is not obligatory, logically after death, it is still not obligatory; Third, regarding the will verse of the 'al-Baqarah, verse 180', according to the 'jumhur', it has been ordained. Jumhur, in this case, they have a different opinion about the arguments that confirmed the verse. According to some of them, the 'al-Baqarah verse 180' was inscribed by the alcohol verse (among others the 'al-Nisak verse:11'). This opinion comes from the opinion of Ibn Abbas.And according to some others, such as 'Ikrimah, Mujahid, Malik, Shafi'i, and others who argue that 'sunnah' can enact 'the al-Qur'an', 'al-Baqarah verse 180' is confirmed by the 'Sunnah' of the Prophet ${ }^{8}$ :

4The religious law is 'taklifi' (ahkamu diniyah taklifiyah), which means a law whose calculation is only between the servant and the god, Abu Zahrah divided this religious law that is 'taklifi' about wills, to 'wujub', 'al-nadab', 'ibahah', 'tahrim', and 'karahah'. (Abu Zahrah, Syarh Qânûn al-Wasiyah, (Kairo : Dâr al-Fikr al-'Arabi , 1978), 216.

${ }^{5}$ Zahrah, Syarh, Ibid.,

6Misno," Wasiat Wajibah Untuk Anak Angkat Dalam Khi Dan Fikih", 'Adliya Vol. 11, No. 1, Juni 2017, p. 102.

${ }^{7}$ Ibnu Qudamah, Al-Mugni, VI. (Beirut: Dâr al-Kitab al-'Ilmiyyah, no year), p. 415

${ }^{8}$ Qudamah, Al-Mugni, p. 415. 


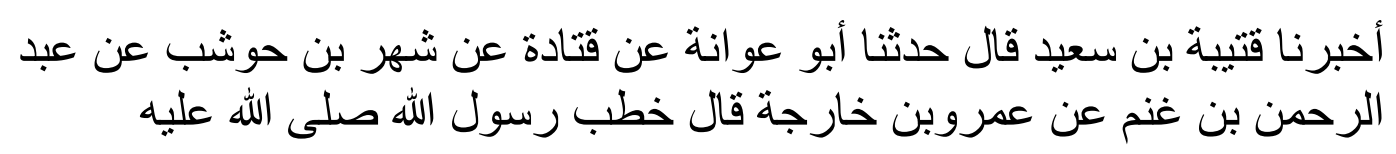

Translation: Reported by 'Qutaibah bin Said', he said to tell us 'Iwanah' from 'Qatadah bin Syahr bin Hausyib' from 'Abdu Allah Abdu al-Rahman bin Ghanam' from 'Amr bin Kharijah' he said: While the Messenger of Allah was preaching, he said, Verily Allah has given rights to everyone who has and no will for the heirs". (HR al-Nasa'i) ${ }^{9}$.

Fourth, the will is prescribed to us, among others, through a hadith from Abu Darda ', he said that the Messenger of Allah once said, Allah has ordered you to take out some of your property, in addition to charity for you. Take out as much as you like (as a will for you). According to Jumhur, this hadith shows that Allah will give benefits to those who want to give some of their property. The purpose is to cover up the good that had escaped him. This shows that the will is not 'fardhu', but it is only circumcised to do so, like other 'Sunnat' practice ${ }^{10}$.

According to Abu Bakr Abdul Aziz, legal wills are obligatory for close relatives who do not receive an inheritance. Opinions like this come from Daud, Masruq, Thaus, 'Yas, Qatadah, and Ibn Jarir. They reasoned with the letter 'al-Baqarah' verse 180 and the 'Hadith' of the Prophet which came from the history of Ibn Umar. According to them, wills that have been legalized are only wills for parents and close relatives who become heirs, while for close relatives who do not receive the legal inheritance, it is still obligatory.

Regarding this issue, 'Ibn Jarir al-Tabari' also cites ten narrations that a will for parents and close relatives who do not receive a legal inheritance is obligatory. The arguments they use include, as put forward by 'al-Rabi', that the letter 'al-Baqarah' verse 180 which explains the obligation of wills for parents and close relatives applies before the inheritance verses are revealed. After the inheritance verses were revealed, the rights of those who received the inheritance were passed down, while those who did not receive the inheritance were still entitled to receive a will ${ }^{11}$.

In addition to the statement above, 'Ibn Jarir' also put forward Ibnu Abbas's, in this case, he said that the right to receive a will for those who receive an inheritance has been abolished, so that the only people who are entitled to receive a will are who are not entitled to inherit.

According to this last group, the hadith "lâ wasiyyata li wârisin", which was used by 'jumhur' as a reason to say that the obligation of a will has been 'manskh', only has a limited meaning, namely the prohibition of wills on heirs or heiress who are entitled to inherit, and does not cover heirs or heiress who is not entitled to inherit.

This latter opinion seems to tend to maintain the obligation of a will for every Muslim who will leave his close relatives, for some reason, cannot get his inheritance after he dies. Thus they view that wills and inheritance remain valid as laws governing the distribution of property to the heirs and close relatives left behind.

\footnotetext{
${ }^{9}$ Imam al-Nasai, Sunan al-Nasai bi Syarh al-Hafizh Jalaluddin al-Suyuthi wa hasyiyah li al-Imam al-Sindi, Chapter III, (Beirut: Dar al-Kitab al-Arabi, no year), p.247.

${ }^{10}$ Ali-Al-Khafif. Ahkâm al-wasiyah Buhûts al-Muqâranah, Tadhammanat syarh Qanûn alWasiyah al-Wâjibah. Ma'hat al-Dirâsât al-Arabiyah al-"aliyah, 1962), p. 296.

${ }^{11}$ Moh. Yasir Fauzi, "Pembagian Harta Dengan Wasiat Wajibah Dan Hibah Dalam Hukum Islam”, Asas, Jurnal Hukum ekonomi Syariah, vol. 9, N0. 1 (2017), p. 106.
} 
According to 'Ibn Hazm' the will must be carried out even though the person who died did not make a will during his life. In his opinion, 'Ibn Hazm' expressed the opinion that every Muslim must give a will to his parents and close relatives who do not inherit it, either because of religious differences, slavery or because of other heirs who prevent it. According to 'Ibn Hazm', they are given a will in the form of a proper share. If the deceased did not make a will before he or she died, it is necessary to take out part of his inheritance to fulfill the need for the will that had not been fulfilled ${ }^{12}$. Then, since 'ulil al-amri' who has the right to determine the affairs of the Muslims, it is their (Uli al-Amri) obligation to issue a portion of the inheritance of that the deceased to fulfill the needs of the will that has not been carried out ${ }^{13}$.

To this issue, taking out a portion of a person's inheritance as a charity, even though he or she did not have a prior will, refers to a will of 'qadhâ'iyah'. This means that the obligation to issue part of the inheritance as a will is no longer based on the presence or absence of a person's will during his life, but on the applicable law or laws (laws set by the authorities). Thus, if a person does not make a will during his life, he is automatically considered to have made a will.

Based on this opinion, the term obligatory will was later born. Suparman Usman defined a will as a will implementation that is not influenced or not dependent on the will of the deceased. This 'will' is still needed to carry out both. So the implementation of the will does not require evidence that the will is spoken or written or desired, but its implementation is based on legal reasons that justify that the will must be implemented ${ }^{14}$.

'Ibn Hazm' argues that the legal will is obligatory for everyone who leaves his parents or close relatives who do not receive an inheritance, and this obligation must be fulfilled even though the person who died did not have a prior will, based on the hadith narrated from Malik, as follows:

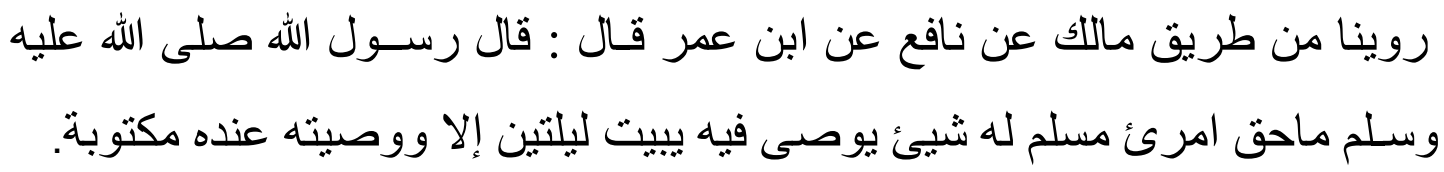

Translation: We have narrated through Malik from Nafi' from Ibn Umar, he said, that Prophet Muhammad SAW. said, It is not the right of a Muslim who has something that he wants to bequeath the night (postponed) until two nights unless he has written his will on his side. (Narrated by HR. Imam Malik) ${ }^{15}$.

As for 'obligatory ('kefarduan')' of taking out some of left property of a person who has died, even though he did not intestate previously. It is also based on the hadith narrated by Malik:

12Ibn Hazm, al-Muhalla, X, (Maktabah Jumhuriyah al-Arabiyah, 1970),p. 419.

${ }^{13}$ Badran Abu al-Ainaini Badran, Ahkâm al-Wasâya wa al-Auqâf, (Iskandariyah: Muassasah Syababi al-Jami'ah, 1982), p. 104.

${ }^{14}$ Suparman Usman and Yusuf Somawinata, Fiqh Mawaris Hukum Kewarisan Islam,(Jakarta: Gaya Media Pratama, 1997), p. 163.

${ }^{15}$ Hazm, al-Muhalla, X, op. cit., p. 420. 


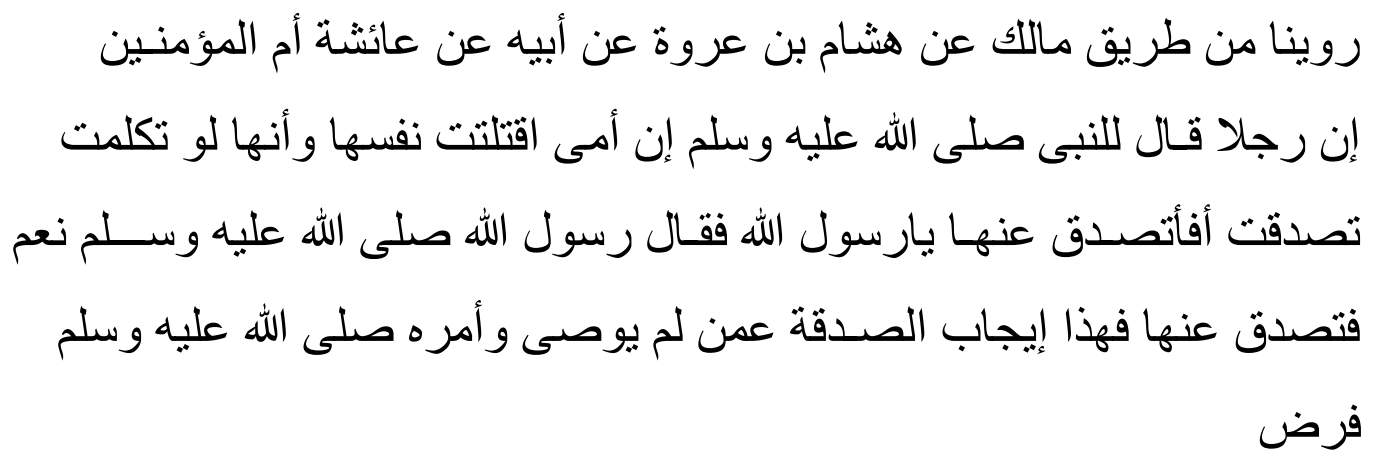

Translation: We have been narrated by Malik from Hisham ibn Urwa from his father from Aisha ummu al-mu 'minin; Verily a man said to the Prophet: My mother has died and she intends to give charity, should I do it, $O$ Messenger of Allah? The Messenger of Allah replied: Yes, do her 'sadaqah'. So this shows the obligation to issue 'sadaqah' for people who do not make a will. And the command of the Messenger of Allah is obligatory." (Narrated by Imam Malik) ${ }^{16}$.

Regarding Ibn Hazm's last opinion, Badran Abu al-Ainaini Badran adds that Ibn Hazm said that the authority is obliged to issue part of the inheritance of someone's will who had died as a will even though he did not have a will. It is based on the idea that the authority should guarantee the rights of their people which have not been implemented ${ }^{17}$.

It is important to point out that Ibn Hazm in his last opinion tends to see the mandatory of will, not only as an obligation of "dniyyah", religious only but also as 'qadhâ'iyyah'. if the obligation is 'dniyyah', only religion, if it is not carried out by someone, there is no obligation for the heirs, heiress, or other people to carry it out. But the obligation of 'qadâ'iyyah', if it has not been carried out, it is obligatory for the heirs or other people, including the authority to carry it out the will ${ }^{18}$.

Legal provisions like this were later used by scholars as one of the legal bases in formulating the concept of a will of 'wajibah'. And it is not wrong if someone mentions Ibn Hazm as the first figure who issued the concept of the will of 'wajibah'.

These are some of the Muslim scholars' opinions who have emerged regarding the law of carrying out wills. the concept of obligatory will arose from different opinions among scholars about the law of carrying out this will like the author stated at the beginning of this paper.

\section{The Owner of the Mandatory of 'Wajibah'}

In principle, parents and close relatives who for some reason cannot receive an inheritance are entitled to get a share of the inheritance through a will of 'Wajibah'. As stated by 'Ibn Hazm', that it is such a law, it is 'fardhu' for every Muslim to give a will to parents and close relatives who do not inherit it, either because of religious differences, slavery, or because of other prevention of heirs. However, because the will of 'Wajibah' later become a law established by law or regulations made by the

${ }^{16} \mathrm{Hazm}$, al-Muhalla, ibid.,

${ }^{17}$ Badran, Ahkâm p, loc. cit.,

${ }^{18}$ Al-Yasa Abubakar, "Wasiat Wajibah dan Anak Angkat", Mimbar Hukum (Jurnal) , No.29. Year. VII, (Jakarta: Al-Hikmah \& DITBAPERA Islam, 1996), p. 95. 
government, the right to receive a will of 'Wajibah' is limited for people who are determined by law.

Ismail stated that there were only two groups of close relatives who were entitled to receive a will of 'Wajibah'. In Egypt and Islamic countries in general in the world stipulate the right to receive the will, and it is for orphaned grandchildren who are prevented or another word 'terhijab' by their uncles or aunts. In Indonesia, the right to obtain the will is both for adopted children and adoptive parents ${ }^{19}$. More specifically, it can be stated that Egypt includes wills of 'Wajibah' in several articles $(76,77$, and 78) of the law of will number 71/1946. According to this law, a will of 'Wajibah' is a mandatory will that is determined by the law on the property of a deceased person. This property is then intended for the descendants of his child who died before or at the same time as him who was not given a will or other form of giving some mandatory wills that he should have received. The amount of property stipulated as a will of 'Wajibah' according to this law, is equal to the portion that should be received by the heir (child of the deceased) who has died by inheritance with a maximum limit of one-third of the inheritance. The purpose of enacting a will of 'Wajibah' is to overcome the right of orphaned grandchildren or other heirs or heiresses such as uncles or aunts ${ }^{20}$.

The compilation of Islamic Law (KHI) in Indonesia, article 209 stated that the will of 'Wajibah' is a mandatory will that is determined by the authorities over the property of a deceased person intended for adopted children or adoptive parents who were not given a will before by the adoptive parents or their adopted children who died with a maximum amount of one-third of the inheritance 21.

The will of 'Wajibah' in the context of KHI in Indonesia was born as a response to the phenomenon of adopted children that occurred in society. In Indonesian society, at least in some societies, adopting children tend to be appreciated and often occurs. The practice of adopting children is not the same as what is known as the commonly known term "tabanni". If "tabanni" means the transfer of lineage from the original parents to adoptive parents, the adoption of children in our society is only to maintenance, fulfillment of living and education, and affectionate relationships as like a child with parents, and does not involve the transfer of kinship relations between the original parents to the adoptive parents ${ }^{22}$.

This practice of adopting a child is very different from the practice of 'tabanni', it is of course beyond the reach of existing legal institutions of "tabanni". It is necessary to give him or her a special legal institution under the values of justice in society. To respond to social realities like this, KHI recognizes child adoption institutions. The permissiveness of adopting children as stated above is contained in Article 71, letter (h) of the Compilation of Islamic Law in Indonesia. In addition to giving recognition to the adoption agency, KHI also acknowledges the existence of a legal relationship between the two. The acknowledgment of the existence of a legal relationship is proven by the KHI by the concept of the will of 'Wajibah', as contained in Article 209 paragraphs (1) and (2).

Although the legal relationship provided by KHI to adopted children and their adoptive parents is not as strong as the inheritance relationship (in this case the

\footnotetext{
${ }^{19}$ Ismail, Wasiat Wajibah: Perbandingan Undang-Undang Wasiat Mesir No. 71 tahun 1946 dan Kompilasi Hukum Islam di Indonesia, (Jakarta: Hayfa Press, 1998), pp. 10-11.

${ }^{20}$ Ismail, op.cit., p. 138.

${ }^{21}$ Ibid.,

${ }^{22}$ Eko Setiawan, Penerapan Wasiat Wajibah Menurut Kompilasi Hukum Islam (KHI) Dalam Kajian Normatif Yuridis, Muslim Heritage, Vol. 1, No. 2,November 2016-April 201, p. 46
} 
kinship relationship), it can at least be used as evidence that KHI has provided a fairly strong response to the existing legal reality. The existence of a will of 'Wajibah' for adopted children, and the contrary for adopted parents, ensures that the adopted child participates in enjoying the inheritance of his adoptive parents. What drives them to provide guarantees so that both of them can enjoy each other's inheritance is the sense of justice that grows and lives in Islamic society in Indonesia. In other words, it seems unfair if the adopted child and his adoptive parents, who have developed love, help, share feelings, and protect each other, do not get any share from the inheritance of one of them.

The phenomenon stated above was explained by Al-Yasa Abubakar in the Will of 'Wajibah' and Adopted Child in Indonesian society. According to him, at least in some societies, child adoption tends to be appreciated and often happens for various reasons. Adoption of children is usually confirmed by customary law (before the birth of KHI) and it often has difficulties, feelings of dissatisfaction, and even accusations of being unfair when one party dies. the adopted child often does not get anything from the inheritance of his adoptive parents. His adoptive parents might not have a will during his life or they did not know that his adopted child was not entitled to inherit from him (according to fiqh). In addition, other methods, such as grants, sometimes also don't work well, maybe after the grant occurs, there will be a fight between the two ${ }^{23}$.

To guarantee that the adopted child and his adoptive parents can enjoy each other's inheritance, KHI has created a legal institution called a will of 'Wajibah' ('Wasiat Wajibah). Of course, this concept may be used to solve the problem between the adopted child and his adoptive parents and there are guarantees for them to receive each other's share of the inheritance.

The granting of the will of 'Wajibah' to adopted children stipulated by KHI, according to Muhammad Daud Ali, was carried out by adapting limited customary law values into Islamic law, due to the shift of responsibility from the original parents to the adoptive parents regarding the maintenance of daily life and education costs based on court decisions as stated in a letter (h) Article 71, concerning General Provisions for Inheritance ${ }^{24}$.

In line with the opinion expressed by Muhammad Daud Ali above, Yahya Harahap explained that the legal basis used in KHI in determining the existence of a will of 'Wajibah' for adopted children is to compromise between Islamic law and customary law.

According to the provisions of Islamic law, adopted children cannot receive an inheritance from their adopted parents, and adopted parents are not entitled to inherit from their adopted children. Such legal provisions, among others, are implied in the word of God:

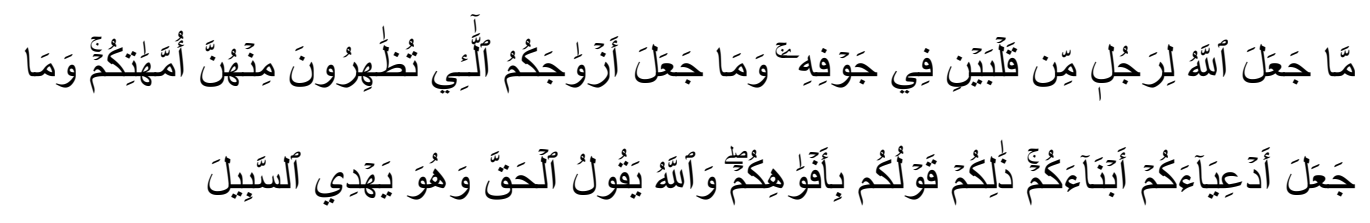

${ }^{23}$ Al-Yasa Abubakar, op. cit., p. 96.

${ }^{24}$ Muhammad Daud Ali, Hukum Islam dan Peradilan Agama (Kumpulan Tulisan), (Jakarta: Rajawali Press, 1997), p. 137. 
Translation: Allah has never made for a person two hearts in his cavity and he has not made your wives whom you 'dzihar' are your mothers and he has not made your adopted children your son or daughter, that is what you say in your mouth. And Allah determines the truth and He shows the (right) way." (Surat al-Ahzab: 4) The 'Surat al-Ahzab' (verse) above denies the existence of a "nasab" relationship between adopted children and adopted parents, as was the case before Islam. As a result, the two cannot inherit each other because they do not have the conditions to inherit each other (in this case, the kinship relationship). With this verse, it is clear that according to Islamic law, adopted children and their adopted parents are not entitled to inherit from each other. However, the juridical reality in customary law that develops among Indonesian people, that adopted children have the same rights and positions as biological children in various ways, including in terms of inheritance is a fact that cannot be denied ${ }^{25}$.

Based on this fact, according to Abdullah Kelip, the Indonesian ulama after conducting 'ijtihad' in compiling the KHI, modified a balance of rights and obligations between the adopted child and his adopted parents through wills of 'Hijabah'. The aim is that the inheritance law applied in Indonesia is in line with the sense of justice under legal awareness in society ${ }^{26}$.

Regarding the alignment of Islamic law with the value of justice, as stated above it is called 'siyâsah al-syar'iyyah' 27 The formulation of article 209 contained in the KHI indicates that the adopted child has no inheritance relationship with his adopted parents. Government, legislators realize that faraid's strict rules regarding who is entitled to become heirs are not the area of ijtihad which is eternal, and 'ta'abbudi', 'siyasa' should help create good conditions for the enactment of syara' law. However, lawmakers in KHI play 'siyâsah al-syar'iyah' by giving will rights to adopted children, a maximum of $1 / 3$ if he does not receive an ordinary will. Determining a will of 'Wajibah' for adopted children is a strategic way to ensure that they share in the inheritance of their adopted parents, who have developed love, help, share feelings, and protect each other ${ }^{28}$.

From the opinion expressed above, Sularno wants to say what has been considered as areas of non-ijtihad if the benefit is desired in certain respects and can still be managed. It means that if the existing inheritance law does not allow for the implementation of the demands for benefit, the other laws that are packaged in such a way exist, and the goal could be achieved as long as it does not conflict with the existing law. Perhaps what it is called as 'siyâsah al-syar'iyyah'. The author views the mandatory will, is not pure. In some aspects, they are the same as inheritance, such as the nature of 'ijbariyah'.

The opinions expressed above do not seem to have clearly stated the legal sources wills of 'Wajibah' contained in the KHI. Everything is still questioned why a will of 'Wajibah' is given to an adopted child.

${ }^{25}$ M. Yahya Harahab, "Materi Kompilasi Hukum Islam", in Muhammad Mahfud MD, (ed) Peradilan agam dan KHI dalam Tata Hukum Indonesia, ( Yogyakarta :UII Press, 1993), p. 93.

${ }^{26}$ Mahfud MD, op. cit., p. 138.

${ }^{27}$ Noel J. Coulson, Conflicts and Tensions in Islamic Jurisprudence, (Edinburg: Edinburg University Press, 1964), p. 68.

28Sularno, “Siyasah Syar'iyah Dalam KHI (Tela'ah terhadap Hukum Kewarisan)”, Jurnal hukum Islam Al-Mawarid, (Yogyakarta: Fak Syari'ah UII, 1997), p. 73. 
To answer this last question, Al-yasa Abubakar's opinion can be expressed which says that the legal basis used to make rules regarding wills of 'Wajibah' for adopted children, as regulated by KHI, as part of 'fiqh' is only consideration of 'almasâlîh al-mursalah'. The wills of 'Wajibah' for adopted people may be applied considering the benefit and customs of some of our society. For example, the reluctance to practice polygamy even though they have not been blessed with offspring for years.

By not denying the previous opinions, in looking for the legal basis of the will of 'Wajibah' according to the KHI, the author is more likely to strengthen the latter opinion, which is based on 'al-maslahah al-mursalah'. The reason is, among other things, the concept of wills of 'Wajibah' in Islamic law is a new concept of law, which is specifically not found in the Quran and Sunnah. In Islamic law, all things that have not been found its law in the Qur'an and Sunnah can be justified and accepted as an Islamic rule for certain benefit with all its requirements.

Compilation of Islamic Law in Indonesia only contains one article and two paragraphs concerning wills of 'Wajibah', and does not clearly state the conditions for the enactment of wills of 'Wajibah' in the verses. However, one condition can be raised, namely: Adopted children or adopted parents who are entitled to receive a will of 'Wajibah' with a maximum amount of $1 / 3$ of the inheritance property of one of the two, do not receive an ordinary will.

It should be stated here that the article only cancels the will of 'Wajibah' for those who have received an ordinary will and does not mention any forms of giving or other forms of 'tasarruf'. It is not clear whether other forms of 'tasarruf' such as grants and others given during life can make him ineligible for a will of 'Wajibah'. It is one condition for wills of 'Wajibah' that exist according to the compilation of Islamic Law in Indonesia.

In the discussions stated above, it has been mentioned who is entitled to a will of 'Wajibah'. However, the author would like to reiterate that those who are entitled to receive a will of 'Wajibah' according to the KHI are adopted children, and adopted parents.

The right to receive a will of 'Wajibah' between an adopted child and his adopted parents applies reciprocally, an adopted child has the right to the inheritance of his adopted parents through a will of 'Wajibah'. The wills of 'Wajibah' do not apply to adopted siblings or adopted parents' siblings ${ }^{29}$. As for what is meant by adopted children here, it is explained by article 171 , letter (h) which reads:

Translation: An adopted child is a child who in terms of maintaining his daily life days, education costs, and so on, the responsibility shifts from the original parents to the adopted parents based on a court decision.

Article 171 above can be understood that the adopted child referred to by KHI is a child who is in the care, educate, and so on, the responsibility from the original parents to the adopted parents is transferred. This article implicitly explains that the adoption of children intended by KHI does not reach the transfer of lineage from the original parents to the adoptive parents. And adoption like this is more social in nature, not to continue the descent as was commonly practiced by people in the past. Nazaruddin explained:

${ }^{29}$ Subiyanti, et al, Implementasi Wasiat Wajibah Untuk Anak Angkat Menurut Kompilasi Hukum Islam (KHI), NOTARIUS, Vol. 12 No. 1 (2019), p. 314. 
Translation: From its historical context, adoption or adoption of children is as old as human civilization on this earth. The inclusion of adoption rules in the code of 'Hummarabi' in the Babylonian era, $k . l 21$ century BC could be one of the evidence. Likewise, in the code of Justinian in Roman times, k.l 450 $B C$, then continued in the French Civil Code at the era of Napoleon in 1804 $A D$. The same thing happened in ancient countries such as Greece, China (Tiongkok), the Arabian Peninsula, and several Asian countries such as India. The motive for implementing adoptions in these countries is the same, to continue the lineage to maintain the integrity of the patrilineal family system (fatherhood). Adopted children are disconnected from their original parents moving to the lineage of the adoptive parents. So that the child becomes his biological child and gets all the full rights like a biological child ${ }^{30}$.

However, after World War I and II there has been a shift in motives in implementing adoption. Adoption is no longer driven by the mere interest continuing the lineage, but it is more driven by the social interest of the child concerned due to a large number of orphans and abandoned children as the consequence of the war ${ }^{31}$.

KHI seems to respond to adoption with this second motive, which is solely for the social interests of the child concerned. The response to the adoption of a child with the second motive may be carried out as an answer to the phenomenon of child adoption that often occurs in Indonesia. Where, as stated by Al-Yasa Abubabakar, that adoption in our country tends to be appreciated and often occurs, especially in marriages that are not blessed with offspring 32 . Those who do not have any children do not divorce or take polygamy as a solution, but they take a close relative or even a foreigner as a foster child to have cared ${ }^{33}$.

According to Islamic 'Shari'ah', adoption of this kind of child is not prohibited, but it is recommended. The aim is to take care of orphans and neglected children with care, love, education, and welfare. These children, in this case, are neither to be biological nor to continue their descendants.

This kind of adoption practice is recognized by KHI through article 171 letter (h) as stated above. The adopted children are given the right to receive a share of the inheritance of their adopted parents through a will of 'Wajibah'. Social interest is the motive for granting of will rights to adopted children in Indonesia. This motive is a reasonable legal solution given by the legal authority in Indonesia in response to a social phenomenon that exists and happens in Indonesia.

Thus the person who is entitled to receive a will of 'Wajibah' according to the Compilation of Islamic Law in Indonesia. Wills of 'Wajibah' are given to adopted children or to adopted parents who have not received a previous will from the deceased. The amount of property as a will of 'Wajibah' is limited to one-third of the inheritance.

\section{Closing}

From the previous discussion, several conclusions can be drawn. A will of 'Wajibah' is a mandatory will that is determined by the authorities (law) on the property of a person who dies based on justifiable legal reasons. The will of 'Wajibah' is intended for parents or close relatives who because of a syara's prohibition cannot get a share of the inheritance.

${ }^{30}$ Nazaruddin, "Masalah Adopsi dan RUU Peradilan Anak", in Mimbar Hukum (Jurnal), No. 25, Year. VII, (Jakarata: Al-Hikmah dan DITBINBAPERA ISLAM, 1996), p. 22.

${ }^{31}$ Nazaruddin, op. cit., p. 25.

32 Al-Yasa Abu Bakar, op. cit., p. 96.

33 Ibid., 
Furthermore, the will of 'Wajibah' was born from 'Ijtihad' and the interpretation of scholars, including Ibn Hazm, based on the verses law of wills stated in the Qur'an and 'Hadith'. This product of ijtihad is then - with various similarities, specifications, and differences - adopted by scholars and legal authorities in various Islamic countries into the form of legislation. Thus the will of 'Wajibah' is a new 'ijtihad', born as an effort to save the rights of people who are considered worthy to receive part of the inheritance of their relatives, while inheritance law does not recommend it.

\section{BIBLIOGRAPHY}

Abubakar, Al-Yasa. "Wasiat Wajibah dan Anak Angkat", Mimbar Hukum (Journal), No.29. Th. VII. Jakarta: Al-Hikmah \& DITBAPERA Islam, 1996.

Badran, Abu al-Ainaini Badran, Ahkâm al-Wasâya wa al-Auqâf. Iskandariyah: Muassasah Syababi al-Jami'ah, 1982.

Hazm, Ibn, al-Muhalla, X, Maktabah Jumhuriyah al-Arabiyah, 1970.

Ismail. Wasiat Wajibah: Perbandingan Undang-Undang Wasiat Mesir No. 71 tahun 1946 dan Kompilasi Hukum Islam di Indonesia. Jakarta: Hayfa Press, 1998.

Khafif, Ali-Al-. Ahkâm al-wasiyah Buhûts al-Muqâranah, Tadhammanat syarh Qanûn al-Wasiyah al-Wâjibah. Ma'hat al-Dirâsât al-Arabiyah al-aliyah, 1962.

Mahmood, Tahir. Family Reform in The Muslim World. Bombai: NM. Tripathi PVT LTD, 1972

------. Personal Law in Islamic Countries. New Delhi: Academic in law and Regional

Misno, Wasiat Wajibah Untuk Anak Angkat Dalam Khi Dan Fikih, 'Adliya Vol. 11, No. 1, Juni 2017

Moh. Yasir Fauzi, Pembagian Harta Dengan Wasiat Wajibah Dan Hibah Dalam Hukum Islam, Asas, Jurnal Hukum ekonomi Syariah, vol. 9, NO. 1, 2017.

Nasai, Imam al-. Tanpa Tahun. Sunan al-Nasai bi Syarh al-Hafizh Jalaluddin alSuyuthi wa hasyiyah li al-Imam al-Sindi, Ch. III. Beirut: Dar al-Kitab al-Arabi

Qudamah, Ibn, Al-Mugni, VI. Beirut: Dâr al-Kitab al-'Ilmiyyah, no year.

Rizkal, Pemberian Hak Waris Dalam Hukum Islam kepada Non-Muslim Berdasarkan Wasiat Wajibah, Jurnal Yudisial Vol. 9 No. 2, 2016.

Setiawan, Eko, Penerapan Wasiat Wajibah Menurut Kompilasi Hukum Islam (KHI) Dalam Kajian NormatifYuridis, Muslim Heritage, Vol. 1, No. 2, November 2016April 2017

Shiddieqy, Hasbi Ash-, Fiqh al- Mawaris, Hukum-Hukum Warisan dalam Syari'at Islam. Jakarta: Bulan Bintang, 1973.

Subiyanti dkk, Implementasi Wasiat Wajibah Untuk Anak Angkat Menurut Kompilasi Hukum Islam (KHI), NOTARIUS, Volume 12 Nomor 1, 2019.

Syiba'i, Mustafa al-. Ahkâm al-Ahliyah wa al-Wasiyah. Damaskus : Mathba'ah Jami'ah, 1961.

Usman, Suparman dan Yusuf Somawinata. Fiqh Mawaris Hukum Kewarisan Islam. Jakarta: Gaya Media Pratama, 1997.

Zahrah, Abu, 1978. Syarh Qânûn al-Wasiyah. Kairo: Dâr al-Fikr al-'Arabi.

------.tt, Ahkâm al-Tirkât wa al-Mawârîs. Kairo: Dar a-Fikr. 